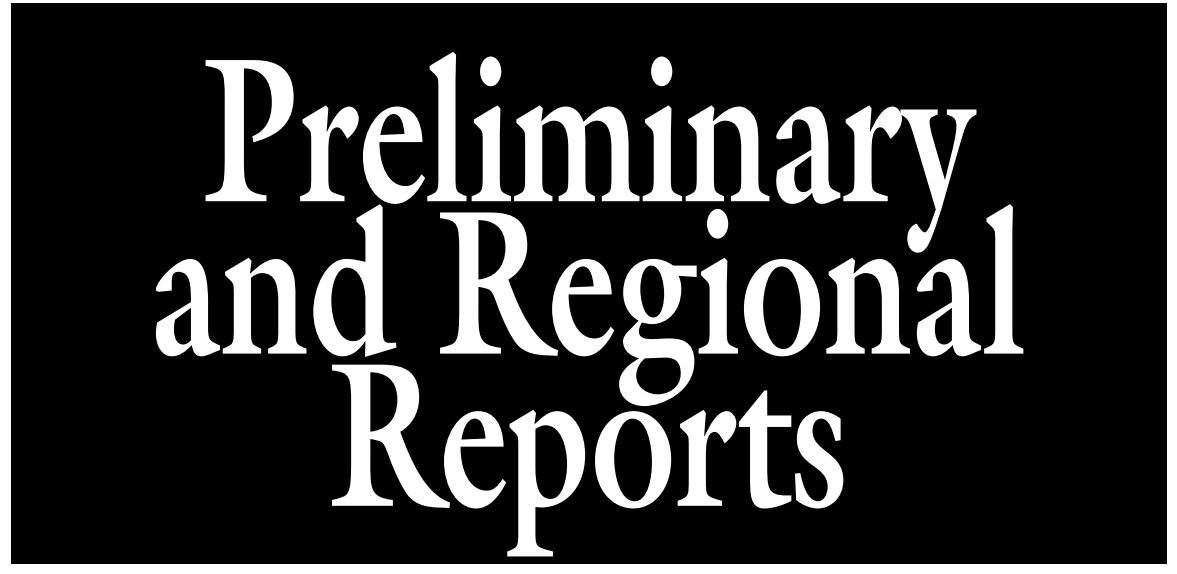

\title{
Evaluation of the Effect of Different Modified Atmosphere Packaging Box Liners on the Quality and Shelf Life of 'Friar' Plums
}

\author{
Celia M. Cantín ${ }^{1}$, Carlos H. Crisosto ${ }^{2,4}$, and Kevin R. Day ${ }^{3}$
}

ADDITIONAL INDEX WORDs. MAP, storage, internal breakdown, gel breakdown, firmness, translucency, Prunus salicina

SuMMARY. The influence of modified atmosphere packaging (MAP) on quality attributes and shelf life performance of 'Friar' plums (Prunus salicina) was studied. Plums were stored at $0{ }^{\circ} \mathrm{C}$ and $85 \%$ relative humidity for a 60 -day period in five different box liners (LifeSpan L316, FF-602, FF-504, 2.0\% vented area perforated, and Hefty liner) and untreated (control). Flesh firmness, soluble solids concentration, titratable acidity, and $\mathrm{pH}$ were unaffected by the box liners. Fruit skin color changes were repressed on plums packed in box liners that modified gas levels and weight loss was reduced by the use of any of the box liners. Plums packed without box liners (bulk-packed) had $\approx 6 \%$ weight loss. High carbon dioxide $\left(\mathrm{CO}_{2}\right)$ and low oxygen $\left(\mathrm{O}_{2}\right)$ levels were measured in boxes with MAP box liners (LifeSpan L316, FF-602, and FF-504). Percentage of healthy fruit was unaffected by any of the treatments during the ripening period (shelf life) after $\mathbf{4 5}$ days of cold storage.

However, after 60 days of cold storage, fruit from the MAP box liners with higher $\mathrm{CO}_{2}$ and lower $\mathrm{O}_{2}$ levels had a higher incidence of chilling injury (CI) symptoms, evident as flesh translucency, gel breakdown, and "off flavor" than fruit from the other treatments. Overall, results indicate that the use of MAP box liners is recommended to improve market life of 'Friar' plums up to 45 days cold storage. However, the use of box liners without gas control capability may lead to CI symptoms in fruit cold-stored for longer periods.

$\mathrm{P}$

lums, like other stone fruit, have a limited postharvest life. They are climacteric fruit and

${ }^{1}$ Departmento de Pomología, Estación Experimental de Aula Dei (CSIC) Apdo. 202, 50080, Zaragoza, Spain

${ }^{2}$ Department of Plant Sciences, University of California at Davis, Kearney Agricultural Center, 9240 South Riverbend Avenue, Parlier, CA 93648

${ }^{3}$ Farm Advisor, Cooperative Extension Tulare County, 4437-B S. Laspina St., Tulare, CA 93274

We acknowledge financial support from Kool Kountry and Sun World. Ms. Celia M. Cantín was supported by a FPU fellowship from Spanish MEC (Ministerio de Educación y Ciencia). We further acknowledge the help on data acquisition of Ms. Monica Escoto and Mr. Tony Calvillo.

${ }^{4}$ Corresponding author. E-mail: carlos@uckac.edu. undergo rapid deterioration after ripening, including softening, dehydration, and decay. Commercial storage conditions $\left[0-5{ }^{\circ} \mathrm{C}\right.$ and $80 \%$ to $95 \%$ relative humidity $(\mathrm{RH})]$ may delay the softening process, but may also lead to the development of storage disorders. Storage disorder symptoms include flesh browning, gel breakdown, mealiness, flesh translucency, red pigment accumulation (bleeding), overripening, and loss of flavor and its extent is genotype affected (Crisosto et al., 1999; Dodd, 1984; Taylor et al., 1995). These storage symptoms are called internal breakdown or chilling injury (CI). Gel breakdown is a gelatinous appearance of the flesh occurring near the plum pit.

Controlled atmosphere (CA) or modified atmosphere packaging (MAP) and RH management are used as supplements to fruit cold storage to limit water loss, delay ripening, and suppress diseases (Beaudry, 1999; Smith et al., 1987). MAP, a practical way to modify the gas environment surrounding the fruit, uses polymeric films with different permeabilities to oxygen and carbon dioxide to prolong the shelf life of fruit and vegetables. Atmospheric modification evolves within the package as a result of the respiration rate of the fruit, temperature, and the gas diffusion characteristics of the film. Obviously, film selection is important to the system of MAP, because proper matching of the commodity characteristics with the film results in the passive evolution of an appropriate atmosphere within the sealed package (Zanderighi, 2001). The beneficial effects of the MAP technique for keeping quality and extending shelf life of fruit and vegetables are well known (Kader et al., 1989). However, MAP performance is sensitive to temperature and under certain conditions, it can create "off flavor" and decay problems, which negate the potential benefit of reducing weight loss. It has been reported that high carbon dioxide $\left(\mathrm{CO}_{2}\right)$ or low oxygen $\left(\mathrm{O}_{2}\right)$ levels may accelerate the production of "off flavor" (Golias and Bottcher, 2003; Kader et al., 1989).

To the best of our knowledge, few or no MAP studies on plum postharvest performance have been conducted; therefore, the aim of the

\begin{tabular}{llll}
\hline $\begin{array}{l}\text { Units } \\
\begin{array}{l}\text { To convert U.S. to SI, } \\
\text { multiply by }\end{array}\end{array}$ & U.S. unit & SI unit & $\begin{array}{l}\text { To convert SI to U.S., } \\
\text { multiply by }\end{array}$ \\
\hline 29.5735 & $\mathrm{fl} \mathrm{oz}$ & $\mathrm{mL}$ & 0.0338 \\
25.4 & inch $(\mathrm{es})$ & $\mathrm{mm}$ & 0.0394 \\
4.4482 & $\mathrm{lbf}$ & $\mathrm{N}$ & 0.2248 \\
1.6093 & mile $(\mathrm{s})$ & $\mathrm{km}$ & 0.6214 \\
$\left({ }^{\circ} \mathrm{F}-32\right) \div 1.8$ & ${ }^{\circ} \mathrm{F}$ & ${ }^{\circ} \mathrm{C}$ & $\left(1.8 \times{ }^{\circ} \mathrm{C}\right)+32$
\end{tabular}


present study was to evaluate the effect of different potential MAP box liners on the quality and shelf life of 'Friar' plums.

\section{Materials and methods}

Plant material and MAP. Boxes of 'Friar' plums were collected during commercial packinghouse operations (Sultana, CA). The 90 corrugated cartons of plums coming from the same orchard, each containing 28 $\mathrm{lb}$ of fruit, were randomly selected from the packing line and assembled in a pallet unit ( 90 boxes). Each treatment consisted of 15 boxes with five boxes as replicates for each of the three evaluation periods. Fruit were packed in corrugated cartons using different box liners and hermetically sealed by hand using a twisted wire. After packing, fruit were forced aircooled overnight to a pulp temperature of $\approx 2{ }^{\circ} \mathrm{C}$, and the full pallet (90 boxes) was transported $\approx 10$ miles in an air-conditioned vehicle to the F. Gordon Mitchell Postharvest Laboratory at the Kearney Agricultural Center, Parlier, CA (Kearney). In this study, five different box liners were used: LifeSpan L316 (Amcor Flexibles, Victoria, Australia), FF-602 (San Jorge Packaging, Santiago, Chile), FF-504 (San Jorge Packaging), $2.0 \%$ vented area (VA) perforated box liner (UTP, Santiago, Chile), and the Hefty liner model 66034 (Hefty, Fort Lauderdale, FL) and compared with bulk-packed fruit (control). On arrival at Kearney, the pallet was placed in cold storage $\left(0^{\circ} \mathrm{C}\right.$ and $85 \% \mathrm{RH})$. Five boxes per treatment were removed from cold storage after 30,45 , and $60 \mathrm{~d}$ for quality attributes and shelf life evaluations. On removal, 15 fruit per box were used immediately for quality evaluations and the remaining fruit in the box were ripened at $20^{\circ} \mathrm{C}$ for market life evaluation (incidence of CI symptoms). The fruit in the boxes reserved for the last evaluation date were also used frequently to monitor weight loss and gas composition.

Fruit Weight Loss. Fruit from all of the boxes from each treatment replication were weighed during the packing operation and reweighed five times during the 60 - $\mathrm{d}$ storage period at $0{ }^{\circ} \mathrm{C}$. The full fruit weight per box was used as an experimental unit. Cumulative weight loss was expressed as percentage loss of original weight.
Gas analysis. Carbon dioxide and $\mathrm{O}_{2}$ evolution was measured for all treatments during storage. At arrival and on seven different times during storage at $0{ }^{\circ} \mathrm{C}$ (up to $60 \mathrm{~d}$ after arrival), $10-\mathrm{mL}$ samples of air gas were taken from the headspace atmosphere of the boxes using a syringe. Samples were injected into a packaging atmosphere analyzer, MAPtest 4050 (Hitech Instruments, Lutton, $\mathrm{UK})$, and $\mathrm{CO}_{2}$ and $\mathrm{O}_{2}$ concentrations were measured and expressed as a percentage.

Quality attributes. Fifteen fruit per each of the five replications (boxes) per treatment were evaluated for fruit quality attributes after 30 , 45 , and $60 \mathrm{~d}$ of storage at $0{ }^{\circ} \mathrm{C}$. Skin color was visually evaluated at each time and expressed as percentage of dark fruit. Dark plums are considered senescent with a short market life by the trade. Flesh firmness was measured using a firmness tester with an 8-mm tip (Western Industrial Supply, San Francisco, CA). For this, skin from opposite cheeks of each fruit was removed with a peeler and firmness calculated as the average of two measurements per fruit. A wedgeshaped slice of flesh was taken from each fruit and combined with nine other slices from each treatment within a replication to form a composite sample. The juice was extracted with a hand press, filtered through cheesecloth, and soluble solids concentration (SSC) measured with a refractometer (Cambridge Instruments, Buffalo, NY). Titratable acidity (TA) was measured with an automatic titrator (Radiometer, Copenhagen, Denmark) by titrating a $3-\mathrm{mL}$ juice sample with $0.1 \mathrm{~N}$ sodium hydroxide to an end point of $\mathrm{pH} 8.2$ and expressed as percent malic acid $(\mathrm{w} / \mathrm{v})$.

$S$ H E L F L IFE Q UA I T Y eVAluation. After 30, 45, and $60 \mathrm{~d}$, 15 fruit per replication treatment were removed from cold storage and ripened at $20^{\circ} \mathrm{C}$ until the flesh firmness reached 8.8 to $12.3 \mathrm{~N}$ before evaluation (Crisosto, 1997). Time to reach the ready-to-eat stage varied (3 to $6 \mathrm{~d}$ ) according to initial maturity. When ripe, they were cut in half transversely along the plane of the suture and visually evaluated for CI symptoms and red flesh color (overripe). CI symptoms of flesh browning, translucency, bleeding, gel breakdown, and mealiness were visually evaluated (Crisosto et al., 1999). Fruit were also

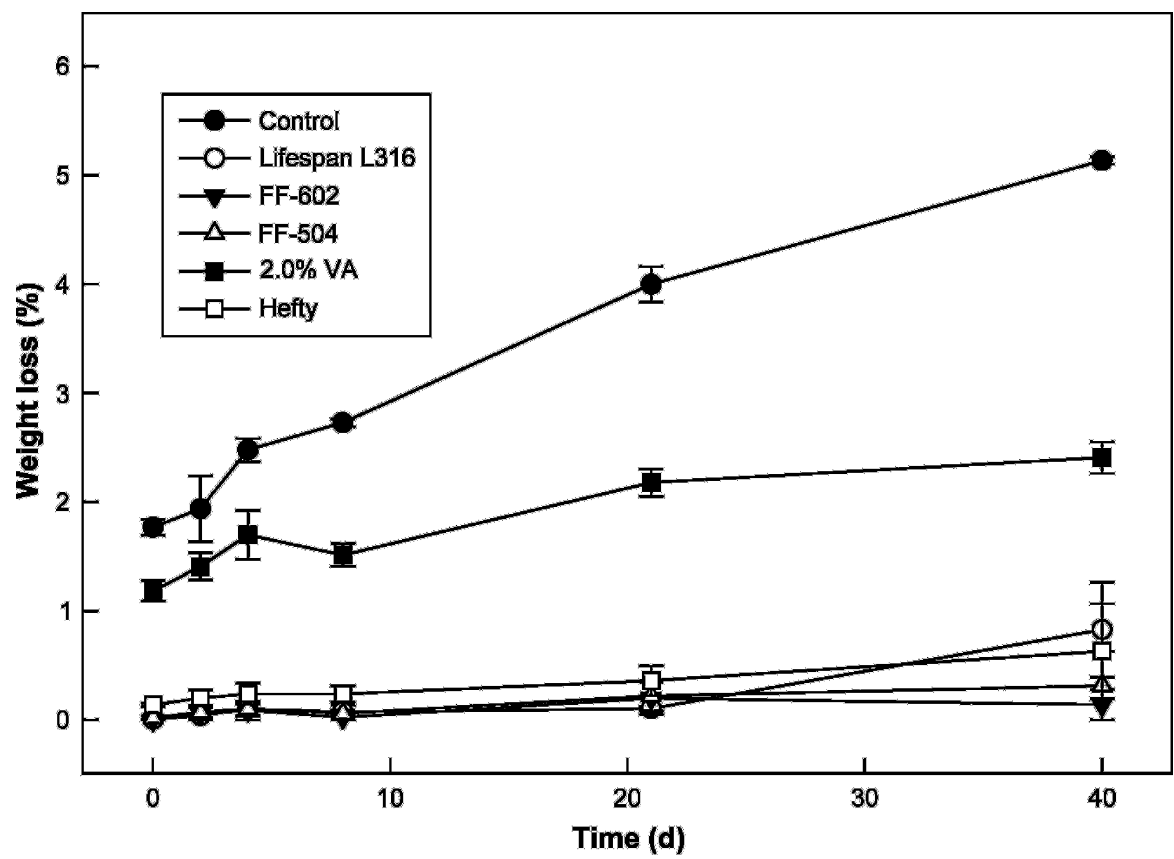

Fig. 1. Effect of different modified atmosphere packaging box liners on weight loss of 'Friar' plums during cold storage at $0^{\circ} \mathrm{C}\left(32.0^{\circ} \mathrm{F}\right)$ for a 60 -d period (mean $\left.\pm \mathrm{SE}\right)$. LifeSpan L316 box liner (Amcor Flexibles, Victoria, Australia); FF-602 box liner (San Jorge Packaging, Santiago, Chile); FF-504 box liner (San Jorge Packaging); $\mathbf{2 . 0} \%$ vented area (VA) perforated box liner (UTP, Santiago, Chile); Hefty box liner model 66034 (Hefty, Fort Lauderdale, FL). 
informally tasted for a feeling of mealiness and/or "off flavor" to corroborate visual assessment. Percentages of dark black-skinned fruit and decayed fruit were recorded at the end of the shelf life evaluation period $(\approx 7 \mathrm{~d})$.

Statistical analysis. All data were subjected to analysis of variance and correlation analysis. Means were separated using least significant difference mean separation at the $5 \%$ or 1\% level using SAS (release 6.03; SAS Institute, Cary, NC).

\section{Results and discussion}

Fruit weight loss. During cold storage, fruit weight loss increased over time, but its rate was treatment-dependent (Fig. 1). By 60 d, fruit packed in any of the solid box liners lost from $0.1 \%$ to $0.3 \%$ of their fresh weight, whereas fruit packed without a box liner (control) lost nearly $6.0 \%$ of their fresh weight. Fruit packed in the $2.0 \%$ VA perforated box liner lost $\approx 2.0 \%$ of their initial weight; this weight loss value was significantly lower than untreated but higher than other MAP treatments. In peaches (Prunus persica) and nectarines ( $P$. persica), we have observed onset of shriveling when fruit weight loss exceeded $6.0 \%$. Because plums are less susceptible to weight loss-induced shrivel, only the losses in the control treatment may affect the cosmetic appearance of the fruit after $40 \mathrm{~d}$ storage. Weight losses evaluated at $60 \mathrm{~d}$ are not presented because of decay incidence that compromised the data.

Gas analysis. The average $\mathrm{O}_{2}$ content varied between $10 \%$ and $20 \%$ among treatments, but there were important changes within each treatment during this 60 -d storage period (Fig. 2). The $\mathrm{CO}_{2}$ level ranged between $\approx 0 \%$ and $10 \%$ among treatments. The $\mathrm{CO}_{2}$ levels for untreated fruit (control) and fruit packed in the $2.0 \%$ perforated box liner and Hefty liner remained low and steady during this storage period. In the boxes of fruit packed using the LifeSpan L316, FF-602, and FF-504 MAP, the $\mathrm{CO}_{2}$ levels increased during this long cold storage period. Fruit packed in the LifeSpan L316 had the highest $\mathrm{CO}_{2}$ content and the lowest $\mathrm{O}_{2}$ content (6.9\% and $14 \%$, respectively) and fruit packed in the FF-602 and FF-504 MAP had intermediate $\mathrm{CO}_{2}$ and $\mathrm{O}_{2}$ levels. Because of their high venting area and gas permeability, the $\mathrm{O}_{2}$ and $\mathrm{CO}_{2}$ levels were not modified on plums packed without a liner (control), Hefty, and the $2.0 \%$ VA perforated box liner.

Quality attributes. Fruit firmness and TA decreased, whereas SSC did not change during the $60 \mathrm{~d}$ of cold storage at $0{ }^{\circ} \mathrm{C}$ (Table 1$)$. As TA declined from $0.42 \%$ to $0.23 \%$ and SSC remained unaffected, the SSC:
TA increased from $\approx 40$ to 55 . TA and firmness loss is a typical pattern in fleshy fruit during their cold storage (Artés-Hernández et al., 2006; Crisosto et al., 2002; Malakou and Nanos, 2005). On each evaluation date $(30,45$, and $60 \mathrm{~d})$, there were no significant differences between treatments for most of the quality attributes measured, except skin color, which was affected by MAP treatments after 45 and $60 \mathrm{~d}$ of cold

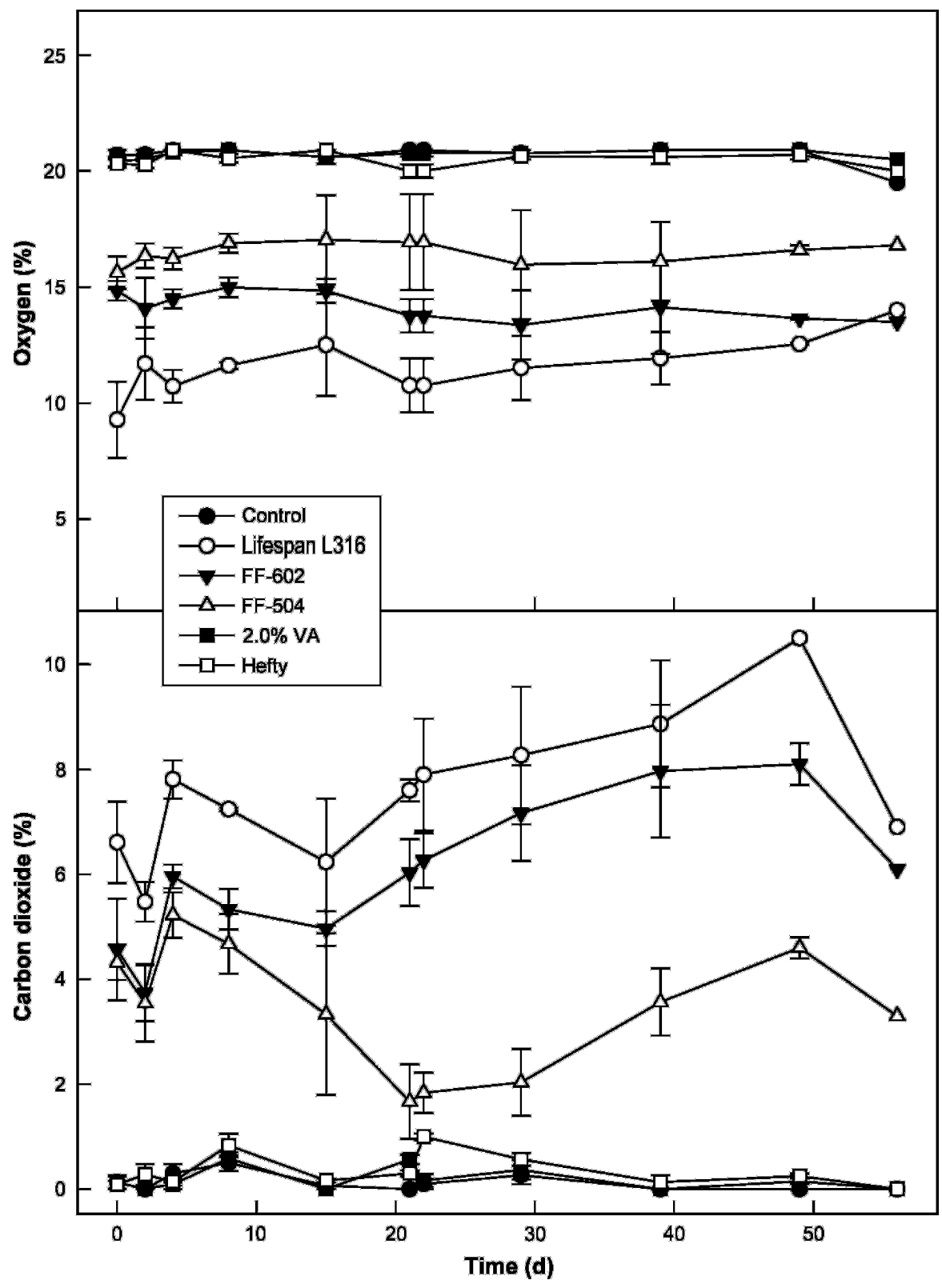

Fig. 2. Carbon dioxide $\left(\mathrm{CO}_{2}\right)$ and oxygen $\left(\mathrm{O}_{2}\right)$ concentrations in boxes of 'Friar' plums with different modified atmosphere packaging box liners during cold storage at $0{ }^{\circ} \mathrm{C}\left(32.0^{\circ} \mathrm{F}\right)$ for a 60 -d period (mean $\pm \mathrm{SE}$ ). LifeSpan L316 box liner (Amcor Flexibles, Victoria, Australia); FF-602 box liner (San Jorge Packaging, Santiago, Chile); FF-504 box liner (San Jorge Packaging); $2.0 \%$ vented area (VA) perforated box liner (UTP, Santiago, Chile); Hefty box liner model 66034 (Hefty, Fort Lauderdale, FL). 
Table 1. Influence of modified atmosphere packaging (MAP) treatments on quality attributes of 'Friar' plums measured during cold storage at $0^{\circ} \mathrm{C}\left(32.0^{\circ} \mathrm{F}\right)$ for a 60 -d period.

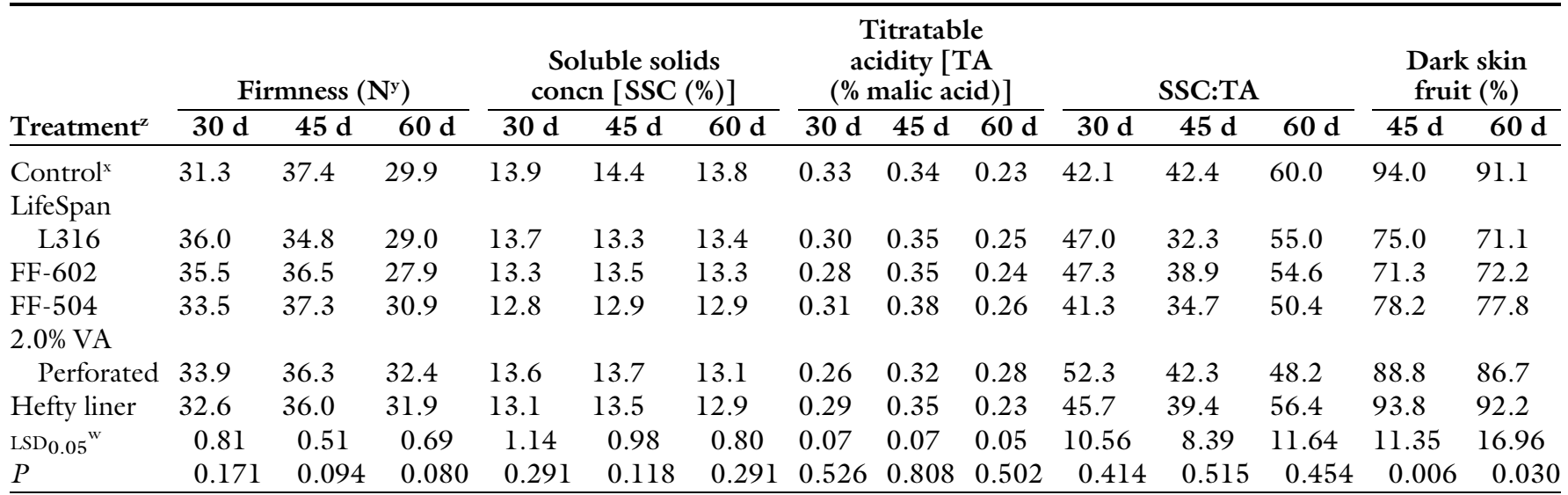

${ }^{2}$ LifeSpan L316 box liner (Amcor Flexibles, Victoria, Australia); FF-602 box liner (San Jorge Packaging, Santiago, Chile); FF-504 box liner (San Jorge Packaging); $2.0 \%$ vented area (VA) perforated box liner (UTP, Santiago, Chile); Hefty box liner model 66034 (Hefty, Fort Lauderdale, FL).

y $1 \mathrm{~N}=0.2248 \mathrm{lbf}$.

Quality attributes of fruit at harvest: firmness $(32.0 \mathrm{~N})$, SSC $(15.2 \%)$, and TA $(0.42 \%)$

"Mean separation by least significant difference (LSD) test at $P>0.05$.

storage. Similar results were reported previously for table grapes [Vitis vinifera (Artés-Hernández et al., 2006; Crisosto et al., 2002)] and peaches (Garner et al., 2001; Lurie, 1993; Malakou and Nanos, 2005) under MAP conditions. On removal after $45 \mathrm{~d}$ cold storage, fruit from the LifeSpan L316, FF-602, and FF-504 treatments had a lower percentage of fruit with dark, dull-colored skin than fruit packed without any box liner, 2.0\% VA perforated, or Hefty box liners. The same treatments also had the highest $\mathrm{CO}_{2}$ accumulation inside the box.

S HELF LIFE QUALITY EVALUATION. CI symptoms such as flesh translucency, gel breakdown, flesh bleeding, decay, and "off flavor" were not observed on ripe fruit evaluated at 30 and $45 \mathrm{~d}$ of cold storage (data not shown). Our informal sensory evaluation at $60 \mathrm{~d}$ of cold storage revealed the presence of "off flavor" (fermented flavor) on fruit packed using the MAP (LifeSpan L316, FF602, and FF-504; data not shown). This agrees with previous work on 'Friar' plums (A.A. Kader, unpublished data). However, after $60 \mathrm{~d}$, the percentage of fruit with gel breakdown ranged from $0 \%$ to $100 \%$ depending on the treatment (Table 2 ). Fruit packed in MAP (LifeSpan L316, FF-602, and FF-504) had $\approx 100 \%$ gel breakdown and also the highest percentage of fruit with flesh translucency (30\% to $70 \%)$. The percentage of fruit with CI symptoms was very low $(0 \%$ to $6.7 \%)$ for fruit packed without box liners or with box liners that did not control gas exchange. The high incidence of flesh

Table 2. Influence of modified atmosphere packaging (MAP) treatments on shelf life attributes of 'Friar' plums measured after $60 \mathrm{~d}$ of cold storage at $0{ }^{\circ} \mathrm{C}$ $\left(32.0^{\circ} \mathrm{F}\right)$ plus $7 \mathrm{~d}$ of ripening at $20^{\circ} \mathrm{C}\left(68.0^{\circ} \mathrm{F}\right)$.

\begin{tabular}{lcccc}
\hline Treatment $^{\mathrm{z}}$ & $\begin{array}{c}\text { Flesh } \\
\text { translucency (\%) }\end{array}$ & $\begin{array}{c}\text { Gel } \\
\text { breakdown (\%) }\end{array}$ & $\begin{array}{c}\text { Red flesh } \\
\text { (overripe) (\%) }\end{array}$ & Decay (\%) \\
\hline Control & 0.0 & 0.0 & 83.3 & 4.4 \\
LifeSpan L316 & 76.7 & 100.0 & 0.0 & 1.1 \\
FF-602 & 30.0 & 100.0 & 0.0 & 0.0 \\
FF-504 & 63.3 & 93.3 & 10.0 & 1.1 \\
$2.0 \%$ VA perforated & 6.7 & 0.0 & 100.0 & 6.7 \\
Hefty liner & 0.0 & 0.0 & 100.0 & 4.4 \\
Significance & & & & \\
$\quad$ LSD $_{0.05}{ }^{\mathrm{y}}$ & 13.78 & 8.55 & 12.09 & 5.71 \\
$P$ & $<0.0001$ & $<0.0001$ & $<0.0001$ & 0.157 \\
\hline
\end{tabular}

${ }^{2}$ LifeSpan L316 box liner (Amcor Flexibles, Victoria, Australia); FF-602 box liner (San Jorge Packaging, Santiago, Chile); FF-504 box liner (San Jorge Packaging); $2.0 \%$ vented area (VA) perforated box liner (UTP, Santiago, Chile); Hefty box liner model 66034 (Hefty, Fort Lauderdale, FL).

'Mean separation by least significant difference (LSD) test at $P>0.05$ translucency and gel breakdown found in the MAP treatments was probably associated with their exposure to the highest $\mathrm{CO}_{2}$ and the lowest $\mathrm{O}_{2}$ levels measured during this 60-d storage period (Fig. 2). Thus, these data raise the hypothesis that high $\mathrm{CO}_{2} /$ low $\mathrm{O}_{2}$ levels enhance development of flesh translucency, gel breakdown, and "off flavor" in 'Friar' plums under long-term cold storage conditions. Extremely low $\mathrm{O}_{2}$ levels or excessively high $\mathrm{CO}_{2}$ levels that induce fermentation can result in the generation of "off flavor" or visible tissue damage (Blanpied et al., 1990). Similar results have been published on other fruit such as strawberries (Fragaria ananassa) and raspberries (Rubus idaeus) in which it was reported that depletion of $\mathrm{O}_{2}$ and accumulation of $\mathrm{CO}_{2}$ resulted in a deterioration of the sensory quality (Van der Steen et al., 2002). In unpublished data, Kader reported that ethanol accumulation occurred after only $45 \mathrm{~d}$ in 'Friar' plums under different $\mathrm{CA}$ conditions at $0{ }^{\circ} \mathrm{C}$. This high level of ethanol may explain the perception of "off flavor" in 'Friar' measured after $60 \mathrm{~d}$ of cold storage.

After $60 \mathrm{~d}$ of cold storage plus $7 \mathrm{~d}$ ripening at $20^{\circ} \mathrm{C}$, there were no differences in dark skin color (data not shown), but the percentage of fruit showing red color flesh (overripe) was significantly lower in plums packed using the LifeSpan L316, FF602, and FF-504 MAP liners than in the other treatments (Table 2). It has been published that $\mathrm{CA}$ and cold 
storage near $0{ }^{\circ} \mathrm{C}$ are beneficial to reduce softening, decay incidence, and skin and flesh color changes, thereby extending fruit postharvest life. However, these benefits may be limited by physiological disorders such as flesh translucency and gel breakdown attributed to CI (Taylor et al., 1995; Truter et al., 1994) and development of "off flavor." $\mathrm{CO}_{2}$ higher than $15 \%$ and $\mathrm{O}_{2}$ lower than $1.0 \%$ have been reported to cause injury symptoms in plums, whereas $0 \%$ to $5 \%$ $\mathrm{CO}_{2}$ was recommended as the ideal range to benefit plum storage but with limited commercial use (Kader, 1997). However, most of these studies were performed on slow-ripening, long market life cultivars such as 'Angeleno', 'Casselman', and 'Roysum' for a period of storage up to 45 d. Our data suggest that $\mathrm{CO}_{2}$ levels higher than $4.0 \%$ during cold storage periods longer than $45 \mathrm{~d}$ may enhance the development of CI symptoms and "off flavor," especially in cultivars with a high ripening rate and short market life. We believe that $\mathrm{CO}_{2}$ or $\mathrm{O}_{2}$ changes may enhance $\mathrm{CI}$ and "off flavor" development reducing market life; thus, the safe length of time for the use of MAP on plums is related to the cultivar potential market life. Therefore, a cultivar with a longer market life may be stored using MAP for a longer time than 'Friar' before the onset of CI or "off flavor."

In these treatments, decay ranged from $0 \%(\mathrm{FF}-602)$ to $6.7 \%(2.0 \% \mathrm{VA}$ perforated box liner), whereas fruit packed in LifeSpan L316, FF-602, and FF-504 had the lowest but not significant incidence of decay and overripe fruit.

\section{Conclusions}

The use of MAP or box liners is a good approach to reduce 'Friar' plum weight loss and maintain the fruit flesh appearance for cold storage periods up to $45 \mathrm{~d}$. However, the use of MAP is not recommended for cold storage periods longer than $45 \mathrm{~d}$ in this cultivar because of enhanced flesh translucency, gel breakdown, and "off flavor" development. For cold storage or shipping periods longer than $45 \mathrm{~d}$, the use of box liners with no or low $\mathrm{CO}_{2}$ or $\mathrm{O}_{2}$ control is suggested to maintain 'Friar' quality. In all cases, it is critical for success that good postharvest practices such as decay control, proper cooling, and temperature control during the postharvest life are applied and enforced.

This preliminary plum MAP study pointed out the needs of screening cultivar response to MAP with emphasis on storage disorders and flavor. Future studies in plum cultivars with different market life should be conducted.

\section{Literature cited}

Artés-Hernández, F., F.A. Tomás-Barberán, and F. Artés. 2006. Modified atmosphere packaging preserves quality of $\mathrm{SO}_{2}$-free 'Superior Seedless' table grapes. Postharvest Biol. Technol. 39:146-154.

Beaudry, R.M. 1999. Effect of $\mathrm{O}_{2}$ and $\mathrm{CO}_{2}$ partial pressure on selected phenomena affecting fruit and vegetable quality. Postharvest Biol. Technol. 15:293-303.

Blanpied, G.D., D.S. Johnson, O.L. Lau, P.D. Lidster, E.C. Lougheed, and S.W. Porritt. 1990. Apples, p. 7-22. In: Lidster, P.D., G.D. Blanpied, and R.K. Prange (eds.). Controlled-atmosphere disorders of commercial fruits and vegetables. Agriculture Canada Pub. 1847/E, Communications Branch, Agriculture Canada, Ottawa, Ontario, Canada.

Crisosto, C.H. 1997. Stone fruit ripening protocol for receivers. Univ. of California, Div. of Agr. and Natural Resources slide set v98-c with cassette, Oakland, CA.

Crisosto, C.H., D. Garner, and G. Crisosto. 2002. Carbon dioxide-enriched atmospheres during cold storage limit losses from botrytis but accelerate rachis browning of 'Redglobe' table grapes. Postharvest Biol. Technol. 26:181-189.

Crisosto, C.H., F.G. Mitchell, and Z. Ju. 1999. Susceptibility to chilling injury of peach, nectarine, and plum cultivars grown in California. HortScience 34:1116-1118.

Dodd, M.C. 1984. Internal breakdown in plums. Deciduous Fruit Grower 34:255256.
Garner, D., C.H. Crisosto, and E. Otieza. 2001. Controlled atmosphere storage and aminoethoxyvinyl-glycine postharvest dip delay post cold storage softening of 'Snow King' peach. HortTechnology 11:598602 .

Golias, J. and H. Bottcher. 2003. Changes in the ethanol content of stored fruits at low oxygen atmosphere. J. Appl. Bot. 77:181-184

Kader, A.A. 1997. A summary of CA requirements and recommendations for fruits other than apples and pears, p. 134. In: A.A. Kader (ed.). Proc. Seventh Intl. Controlled Atmosphere Res. Conf., University of California, Davis.

Kader, A.A., D. Zagory, and E.L. Kerbel. 1989. Modified atmosphere packaging of fruits and vegetables. Crit. Rev. Food Sci. Nutr. 28:1-30.

Lurie, S. 1993. Modified atmosphere storage of peaches and nectarines to reduce storage disorders. J. Food Qual. 16:57-65.

Malakou, A. and G.D. Nanos. 2005. A combination of hot water treatment and modified atmosphere packaging maintains quality of advanced maturity 'Caldesi 2000' nectarines and 'Royal Glory' peaches. Postharvest Biol. Technol. 38:106-114.

Smith, S., J. Geeson, and J. Stow. 1987. Production of modified atmospheres in deciduous fruits by the use of films and coatings. HortScience 22:772-776.

Taylor, M.A., E. Rabe, G. Jacobs, and M.C. Dodd. 1995. Effect of harvest maturity on pectic substances, internal conductivity, soluble solids and gel breakdown in cold stored 'Songold' plums. Postharvest Biol. Technol. 5:285-294.

Truter, A.B., J.C. Combrink, and L.J. von Mollendorf. 1994. Controlled-atmosphere storage of plums. Deciduous Fruit Grower 44:373-375.

Van der Steen, C., L. Jacxsens, F. Devlieghere, and J. Debevere. 2002. Combining high oxygen atmospheres with low oxygen modified atmosphere packaging to improve the keeping quality of strawberries and raspberries. Postharvest Biol. Technol. 26:49-58.

Zanderighi, L. 2001. How to design perforated polymeric films for modified atmosphere packs (MAP). Packaging Technol. Sci. 14:253-266. 